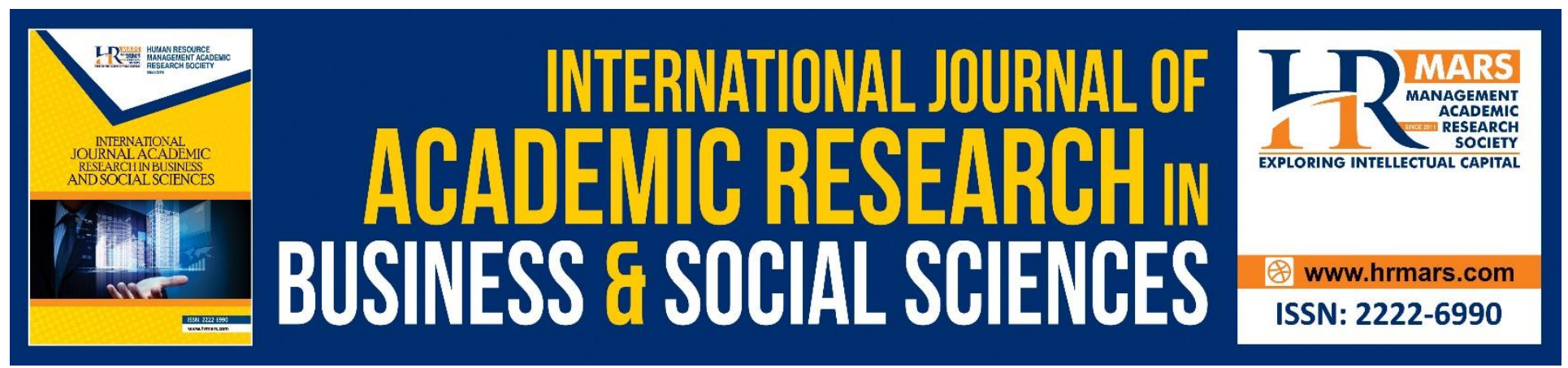

\title{
What Hinders Non-Halal Certified Restaurants' Adoption of Halal Certification? A Qualitative Study
}

\section{Hazrina Ghazali and Lim Siew Wen}

To Link this Article: http://dx.doi.org/10.6007/IJARBSS/v10-i10/8275

DOI:10.6007/IJARBSS/v10-i10/8275

Received: 09 September 2020, Revised: 20 September 2020, Accepted: 19 October 2020

Published Online: 25 October 2020

In-Text Citation: (Ghazali \& Wen, 2020)

To Cite this Article: Ghazali, H., \& Wen, L. S. (2020). What Hinders Non-Halal Certified Restaurants' Adoption of Halal Certification? A Qualitative Study. International Journal of Academic Research in Business and Social Sciences, 10(10), 1137-1158.

\section{Copyright: (c) 2020 The Author(s)}

Published by Human Resource Management Academic Research Society (www.hrmars.com)

This article is published under the Creative Commons Attribution (CC BY 4.0) license. Anyone may reproduce, distribute, translate and create derivative works of this article (for both commercial and non-commercial purposes), subject to full attribution to the original publication and authors. The full terms of this license may be seen at: http://creativecommons.org/licences/by/4.0/legalcode

Vol. 10, No. 10, 2020, Pg. 1137 - 1158

Full Terms \& Conditions of access and use can be found at http://hrmars.com/index.php/pages/detail/publication-ethics 


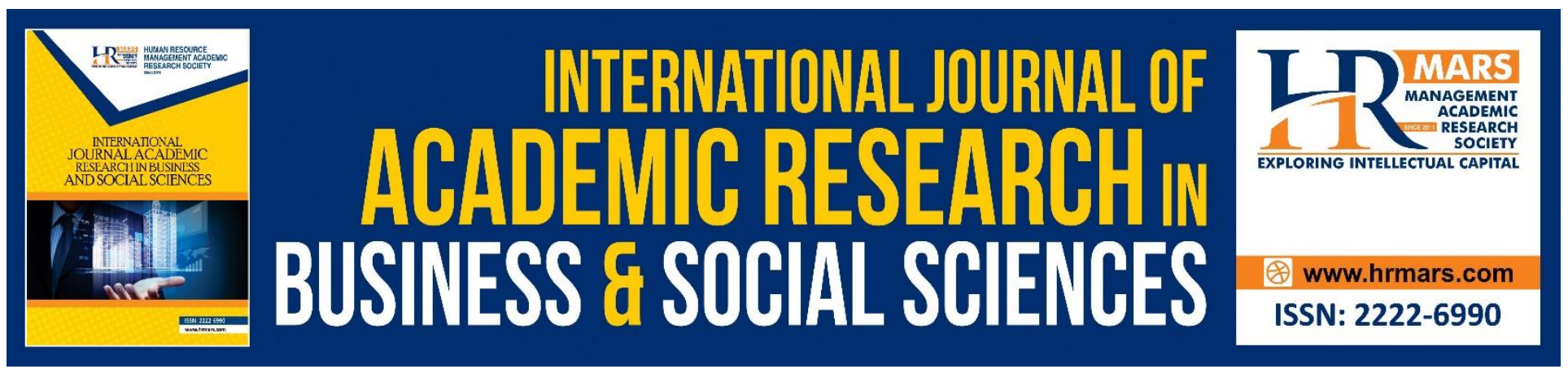

\title{
What Hinders Non-Halal Certified Restaurants' Adoption of Halal Certification? A Qualitative Study
}

\author{
Hazrina Ghazali and Lim Siew Wen \\ Department of Food Service and Management, Faculty of Food Science and Technology, Universiti \\ Putra Malaysia, Serdang Selangor, Malaysia
}

\begin{abstract}
Despite the halal certification is becoming important for many restaurants in Malaysia, the adoption of this halal certification is not mandatory. Some non-halal certified restaurants displayed 'pork-free' signage to attract more customers and gain more sales. Hence, this study is conducted to explore the perception of restaurant operators on halal certification adoption, explore factors that involved in adopting halal certification and explore restaurant operators' perception towards the usage of 'porkfree' signage. This study employs qualitative research approach by using face-to-face interview. The data was gathered through semi-structured interview and a total of 12 restaurant operators from restaurants without halal certification but serving pork free food were interviewed. The interview data was analyzed manually by transcribing word by word. Findings revealed that majority of the informants perceived that halal certification is important. Six of informants did not apply for halal certification due to the presence of non-halal ingredients, certification application procedure and consumer-employee interaction. In addition, majority of the informants perceived that 'pork-free' signage had a poor effect on attracting Muslim customers due to customer faith and choice.
\end{abstract}

Keywords: Halal Certification, 'Pork-Free' Signage, Restaurant Operators, Non-Halal Certified Restaurants, Putrajaya

\section{Introduction}

Why halal industry is getting more developed? The reason is the estimated per capita for halal food is USD 0.85 (RM3.23) per day, hence the global demand for halal food is US\$ 560 billion (RM 2.12 trillion) per year with 1.8 billion Muslim populations worldwide (Abdul Manaf, Cheng, \& Nurwahida, 2013; Nur, Rahman, Saleh, Rahman, \& Hashim, 2011; Talib, Zailani, \& Zainuddin, 2010). Due to this great potential, this halal industry has been developing rapidly, not only the halal food and beverage sector, but also the non-food sectors including halal pharmaceuticals, halal cosmetics, Islamic finance and halal logistics (Malaysia External Trade Development Corporation, 2017). In the particular food and beverage sector, it includes food service industry that the food premises which involve preparing, serving or selling any food such as cafeteria, restaurant and bakery shop (Jabatan Kemajuan Islam Malaysia, 2015). The multinational food manufacturer like Nestle, world's leading fast food restaurant like McDonalds and giant retailer like Carrefour have obtained halal certification to expand 
INTERNATIONAL JOURNAL OF ACADEMIC RESEARCH IN BUSINESS AND SOCIAL SCIENCES Vol. 10, No. 10, 2020, E-ISSN: 2222-6990 @ 2020 HRMARS

their business in Muslim countries (Awan, Siddiquei, \& Haider, 2015; Nordin, 2009). The halal logo for the food premise must be displayed at visible places upon obtaining the halal certification to inform the customers that the food premises are permissible to be patronage by Muslims and the food served to customers are all met halal requirements (Shafie \& Othman, 2006; Syed Marzuki, 2012).

That is why halal tourism has been introduced to fulfill the demand and expectation of Muslim tourists ("Halal Tourism Explained," 2014). Generally, consumers are looking for the restaurants that serving halal food and hotels with dedicated prayer areas as well ("Halal Tourism Explained," 2014; The Guardian, 2017). Therefore, halal certification is the best guide for them to know whether the restaurant is serving halal food or not (Divakaran, 2016). Besides, In Malaysia society, there are three main races exist, which are Malays who are Muslim, Chinese who are Buddhist in majority and Indians who are Hindu in common (Rezai, Mohamed, \& Nasir Shamsudin, 2012). Apart from Muslim tourists, the Malay Muslims in Malaysia are required to consume halal food too (Haque, Sarwar, Yasmin, Tarofder \& Hossain, 2015). The Malay Muslim population which is around $60.4 \%$ in Malaysia (Ahmad, Abaidah, \& Yahya, 2013) is estimated to demand more than RM 5 billion a year if the estimated per capita expenditure for food is RM 1 per day (Talib et al., 2010). Hence, the Muslim customers as well as the Muslim tourists will look for the halal logo that associated with halal certification to confirm the Halal of food products as well as the halal status of food premises (Shafiq, Haque, \& Omar, 2015). Again, halal certification adopted by the restaurant operators plays an important role to inform the Muslim consumers that the products served and the food supply chains are halal. However, a phenomenon arises where some restaurants do not display halal certification but the operators claim the food offered is still halal (Message et al., 2018). Besides, some restaurants operators have displayed 'pork-free' signage that confuse the Muslim population and capture them as their customers too (Lim, 2016). Halal is a hidden quality that should be preserved along the food processing chain before reaching its consumers; in other words, halal should be applied from farm to fork (Lim, 2016; Syed Marzuki, 2012). Thus, 'pork-free' signage is not enough to prove the restaurants are halal because it just simply means that pork and pork-related products are not used in the preparation of dishes (Balakrishnan, 2016; Ismail, 2016). It is considered as an offence under Trade Descriptions Act 2011 as long as the restaurants has attempted to confuse Muslims and has misrepresented themselves as 'pork-free' but serving pork in actual case (Lim, 2016).

Should 'pork-free' signage be eliminated from the foodservice industry under the consideration of the issue? Instead of considering prohibiting 'pork-free' signage in foodservice industry, it is important to understand the perception of restaurant managers of those restaurants first, whether they are aiming to capture the Muslim population with 'pork-free' signage or they are aiming for the profit only. Unfortunately, there is just a little literature was focusing on the restaurant operators' viewpoint but majority of the literature were focusing on the restaurant operators' expectation on halal certification. In terms of halal certification, the restaurant operators are having positive attitude towards it or they perceive that 'pork-free' signage is more important than halal certification; of interest this research attempts to answer the questions. Therefore, this research attempts to deepen the growing halal literature by exploring the perception of restaurant operators in non-halal certified restaurants towards halal certification adoption. 
INTERNATIONAL JOURNAL OF ACADEMIC RESEARCH IN BUSINESS AND SOCIAL SCIENCES Vol. 10, No. 10, 2020, E-ISSN: 2222-6990 @ 2020 HRMARS

Since Malay Muslim is the largest population in Malaysia, they are expected to have greater awareness towards halal concept and look for halal logo when dining at the restaurants outside. However, recent study pointed out that actually Malaysian Muslim customers have good understanding in halal concept which is obligated in their religion, yet they put little effort only on identifying the halal certified restaurants when they are eating out (Ahmad, Abaidah \& Yahya, 2013). There are still a number of Muslim customers who dine in at the 'pork-free' or halal claimant restaurants without halal logo (Ali, Marzuki, Kader, \& Mat Yunus, 2016). Added to that, Khalek (2014) found that more than half of the young customers (57\%) are not aware of the halal status of the fast food restaurants and chain coffee shops, yet most of them (79.2\%) agreed that they will not dine in a non-halal certified restaurant. The contradiction of the statement raises doubt towards their actual attitude on the halal status of restaurants.

The indistinct attitude of Muslim customers towards recognizing the halal certification has discouraged the restaurant operators to adopt halal certification; they use 'pork-free' signage instead. Based on the signage, the restaurants are claimed to be halal even though they are not being verified by JAKIM (Ali et al., 2016); hence, the restaurants are called halal claimant restaurants. On a newspaper article, JAKIM had risen up the issue of 'pork-free' signage on restaurants (Lim, 2016). Added to that, Haroun, Zahari, Hemdi and Zulkifly (2014) also discover the phenomenon that restaurant operators in Malaysia tend to adopt 'pork-free' signage as a promotional strategy to capture Muslim customers, but in fact the restaurants are not systematically halal. Do they think that adoption of halal certification is less important since 'pork-free' signage can capture the Muslim population?

At this point, there are studies have been done on the perception of restaurant operators towards the importance of adopting halal certification in the restaurant industry (Syed Marzuki, 2012; Syed Marzuki, Hall, \& Ballantine, 2012, 2014), but there is little study on their perception towards the non-adopting halal certification phenomenon. Thus, the interest of this research is to understand the phenomenon of non-adopting halal certification, that is, the negative attitude of restaurant operators in the non-halal certified or 'pork-free' restaurants towards halal certification, at the same time explore their perception on the usage of 'pork-free' signage. This is because the literature on this issue is still scarce. The negative attitude of restaurant operators towards halal certification and usage of 'pork-free' signage might become threats and hinder Malaysia from achieving the goal to be the global halal hub by 2020.

\section{Literature Review Halal Certification}

Halal is a product attribute that cannot be evaluated easily by consumers through observing and tasting the food (Rezai et al., 2012; Yunos, Mahmood, \& Mansor, 2014). Singapore, Indonesia and Thailand are the countries that having halal certifying body (Noordin, Hashim, \& Samicho, 2009). Majlis Ulama Islam Singapura (MUIS) is the halal certifying body that has been established in Singapore whereas Lembaga Pengkajian Pangan, Obat-Obatan dan Kosmetika Majelis Ulama Indonesia (LPPOM MUI) is the halal certifying body in Indonesia. In Malaysia, the halal certifying body called Department of Islamic Development Malaysia (JAKIM) which is authorized by the government in 1994. However, the halal certification for food has been conducted throughout Malaysia since 
INTERNATIONAL JOURNAL OF ACADEMIC RESEARCH IN BUSINESS AND SOCIAL SCIENCES Vol. 10 , No. 10, 2020, E-ISSN: 2222-6990 @ 2020 HRMARS

1982 (Marzuki, Hall \& Ballantine, 2014) so that the consumers, especially the Muslim consumers, can identify which food products and food premises are halal (Rezai et al., 2012; Shafie \& Othman, 2006; Syed Marzuki et al., 2012).

According to JAKIM (2014), halal certification is an authorized document declaring the halal status of a product or a service based on Malaysia halal certification scheme issued by the competent authority, which are JAKIM, MAIN/JAIN. Department of Islamic Development of Malaysia (JAKIM), which was established by Malaysia government on $1^{\text {st }}$ Jan 1997, is the authorized body to issue the halal certification (Badruldin et. al , 2012) for national and international markets (Ahmad, Rahman, Othman \& Abidin, 2016) in various categories such as cosmetics, pharmaceuticals and leather products (Tieman, 2015). Since JAKIM has stringent certification procedure in issuing halal certification, it is recognized worldwide that ease the process of expanding the halal industry in Malaysia and attaining the vision of becoming a global halal hub (Badruldin et. al , 2012). On the other hand, State Islamic Religious Department (JAIN)/State Islamic Religious Council (MAIN) are responsible for issuing the halal certification and logo for domestic market only (Noordin, Noor, Hashim \& Samicho, 2009; Ahmad, Rahman, Othman \& Abidin, 2016). According to Marzuki, Hall and Ballantine (2011) and Badruldin et al. (2012), halal certification is an inspection of food processes along the whole food supply chain, including slaughtering, processing, handling and storing. Accodring to Jabatan Kemajuan Islam Malaysia (2015), the general requirements for certification of food premise based on are:

- Equipment used should be free from najs, which refers to impurity such as blood, urine and faeces, and also free from harmful materials and results in side effects to the products produced.

- Appliances/brushes should be free from animal hair.

- The arrangement of equipment and goods should be neat, tidy and safe.

- Non-halal food and beverages are prohibited in the premise.

- The premise should have an effective control system from premise that prepare or process non-halal materials

- All central kitchens and outlets for chain restaurants, franchise and food court should apply for halal certification

- Liquor and liquor-based materials is prohibited in the halal kitchen.

In general, there are five stages for halal certification application, which are document evaluation and approval, premise inspection/ audit, report writing, panel committee and recommendation, issuance of halal certification and monitoring and enforcement (Noordin et al., 2009). 
INTERNATIONAL JOURNAL OF ACADEMIC RESEARCH IN BUSINESS AND SOCIAL SCIENCES Vol. 10, No. 10, 2020, E-ISSN: 2222-6990 @ 2020 HRMARS

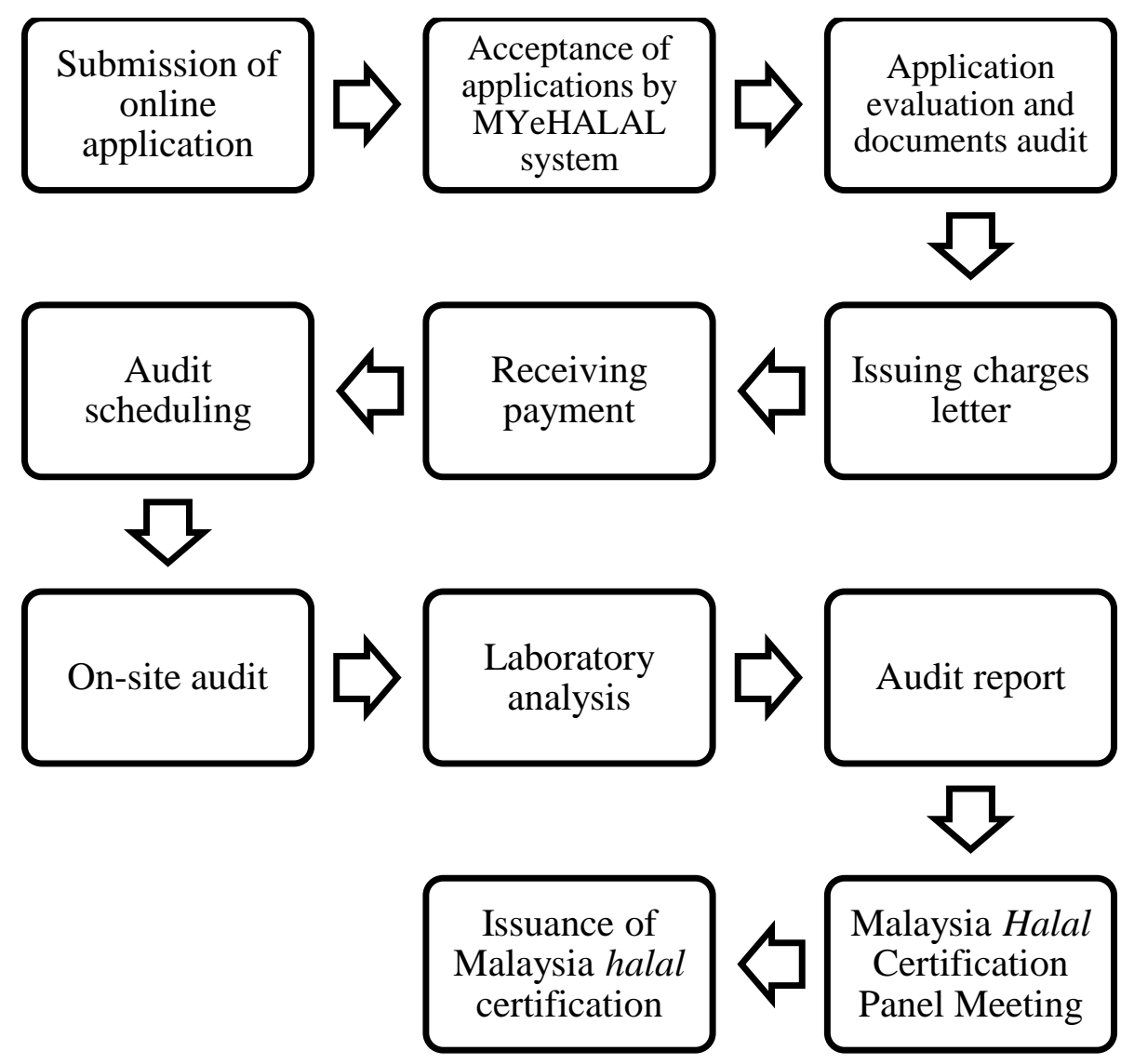

Figure 1: Malaysia halal certification process flow chart. Adapted from "Manual Procedure for Malaysia Halal Certification", by Jabatan Kemajuan Islam Malaysia, 2015, p. 62.

Apart from obtaining halal certification, the food premise must also obey the Malaysian Standard MS1500: 2009 General Guidelines on the Production, Preparation, Handling and Storage, Food Act 1983, Food Regulations 1985 and Food Hygiene Regulations 2009 (Jabatan Kemajuan Islam Malaysia, 2015). In addition, the halal system adopted by a food premise will comply with the Hazard Analysis Critical Control Point (HACCP) for quality assurance (Marzuki et al., 2014). In terms of the certification fee, the fee rate is different based on size of the food premise operation, which can be differentiating by the annual turnover.

In terms of application fee, it is classified according to the size of the company and annual sales or gross sales. The halal certification is valid for every two years upon application and the renewal of certification will be the same as the application fee.

Table 1: Halal Certificate Application Fee

\begin{tabular}{lll}
\hline Application Fee & Annual Sales & Number of Employees \\
\hline RM 200 & $<$ RM 500,000 & $<50$ \\
\hline RM 800 & RM500,000-RM 25,000,000 & $50-150$ \\
\hline RM 1600 & $>$ RM 25,000,000 & $>150$ \\
\hline
\end{tabular}

Note. Retrieved from FAQ and Pricing DagangHalal. 
INTERNATIONAL JOURNAL OF ACADEMIC RESEARCH IN BUSINESS AND SOCIAL SCIENCES Vol. 10, No. 10, 2020, E-ISSN: 2222-6990 @ 2020 HRMARS

Thus, a food premise with displayed halal certification and logo is considered using the permissible ingredients to prepare food in a halal-hygienic environment which corresponds to the Malaysia halal standard and it is permissible for Muslim consumers to patronize and consume the food and beverages (Shafie \& Othman, 2006).

\section{Attitude of Restaurant Operators}

There are only 101 hotels have grabbed halal certification throughout the Malaysia (Zailani, Omar \& Kopong, 2011) where 1858 hotels have registered with Ministry of Tourism (Malaysia Food Service-Hotel Restaurant Institutional Annual 2016 , 2016). From the study of Zailani, Omar and Kopong (2011), they pointed out that most of the hotel managers in non-halal hotels were lack of understanding towards halal certification and perceived adoption of halal certification was not significant. Since their target population is mostly non-Muslim, so they still can operate the hotel successfully without adopting the Halal certification. In restaurant industry, there were three distinct attitudes among restaurant managers towards adopting Halal certification, which were advocating adoption of Halal certification, being ambivalent towards adoption of halal certification and focusing on compliance cost of adopting Halal certification (Marzuki et al., 2014). In general, Muslims were more likely to advocate the adoption of halal certification. Although Chinese were more likely to be ambivalent towards adoption of halal certification, Chinese still respected the Islamic dietary prohibitions and recommended that practicing the Islamic customs and values was significant in Halal-certified restaurants. The mutual agreement of restaurant managers towards the significance in adopting the halal certification is in line with the study of Marzuki, Hall and Ballantine (2011). However, Rahman, Saleh, Rahman and Hashim (2011) stated that non-compliance attitude towards halal standard among restaurant operators was the significant factor that contributed to the low adoption of halal certification, which is parallel to the study of Zailani et al. (2011). Surprisingly, $80 \%$ of the informants in the study were Muslim and they served food to Muslim. Since the findings of the studies within the restaurant industry are not parallel, critical questions arise as to how restaurant operators in non-halal certified restaurants perceive the importance of the adoption of halal certification?

\section{Factors Hindering the Restaurant Operators from Adopting Halal Certification 'Pork-Free' Signage}

Halal certification as well as halal logo is the important symbol that represents the halal status of the food premises and also food products. However, there is a phenomenon occurs in which the food restaurant operators adopted Quranic verses or Arabic characters to inform indirectly to the consumers that the premise is operated by Muslim and halal foods are served. Similarly, a new "Islamic" image, which is 'pork free' status, has been detected in Kuala Lumpur and Selangor areas (Haroun, Mohd Zahri, Hemdi, \& Zulkifly, 2014). This issue has been concerned by well-known Malaysian political Datuk Dr Asyraf Wajdi Dusuki, and he appealed that Muslims must always conscious of the halal status of the restaurants because 'pork-free' signage does not mean the food served is halal (Balakrishnan, 2016).

There are three types of pork free restaurants suggested by a previous study (Haroun et al., 2014). The first type is the restaurants awarded halal certification by JAKIM that are pork free and alcohol free. The second type is the restaurants without halal certification serve pork free food but 
still serve alcohol for non-Muslim consumers. The third type is the restaurants, which are operated by non-Muslims, serving pork free or so called halal food without halal certification. Yet, this is still a new phenomenon that still lack of studies research on the phenomenon. An author of a newspaper article claimed that 'pork-free' signage is not causing any confusion since it is only indicated that the particular restaurant does not use pork or pork-related products in its dishes; in other words, 'porkfree' is not equal to halal (Ismail, 2016). Meanwhile, 'pork-free' signage will be spread over the restaurant industry instead of halal certification since it is common that restaurant industry players are mimicking rival's strategy (Ab Talib, Abdul Hamid, \& Ai Chin, 2015).

\section{Certification Procedure}

Halal certification application is a lengthy process since it has ten steps to be done before issuing the halal certification and logo. The steps are must for clarification and verification, but the implementation of each task at each steps always create problems (Noordin et al., 2009) which results in slow speed in issuing halal certification (Shafie \& Othman, 2006). Both applicants and the internal actors of JAKIM contribute to the inefficiency in issuing halal certification (Noordin et al., 2009; Yusuf, Shukor, Salwa, \& Bustamam, 2015). For the applicants, majority of the applicants have low understanding towards the halal certification procedure. They might send in the incomplete documents to JAKIM and they have to resubmit the documents again which contribute to delay in time. Besides, there are always lacks of expertise that handle the halal certification procedure in JAKIM, hence the new and inexperienced staffs have contributed to the operational inefficiency and reduce the approval rate. The approval rate is about 70-80 percent in common (Badruldin et. al , 2012). One of the evidences is only 75 percent of total applications were awarded halal certificates in 2007. In their findings, most of the applicants perceived a low rating for the service quality of JAKIM since the services offered by JAKIM did not match their expectations. This revealed the weakness of JAKIM's system in delivering service which is parallel to the ineffective operation that revealed by the two studies. In summary, JAKIM's low service delivery system will absolutely hold back the food industry players from adopting halal certification even though adopting halal certification can be a competitive advantage for their business (Ab Talib, Ai Chin, \& Fischer, 2017).

\section{Cost of Implementation}

According to the study of Marzuki et al. (2014), there were a group of "compliance cost focused" restaurant managers, about 202 informants (31.42\%), perceived halal certification was significant to restaurant but the certification process took time and costly. They are concerning very much about the fees, duration taken for completing the certification procedure, complying and maintain the halal standard in their business. An additional cost will be required for setting up a halal certified business since the company has to purchase new equipment to segregate the halal and nonhalal products that in line with halal standard (Prabowo et al., 2015; Yusuf et al., 2015). Apart from that, hiring the Muslim workers, Muslim supervisor and halal executive and also the consultants or experts from outside the company if needed for being in compliance with the halal standard will be high cost expenditure too. For food manufacturers, Prabowo et al. (2015) has revealed the food dealers were reluctant to adopt the halal certification since they have to renovate the factory environment to prevent the products contamination according to the halal standard. Likewise, the restaurant managers have to launch the Halal Assurance System by referring to HAS 2011 if the size of operation is large (Manual Procedure for Malaysia Halal Certification (Third Revision), 2014). In 
INTERNATIONAL JOURNAL OF ACADEMIC RESEARCH IN BUSINESS AND SOCIAL SCIENCES Vol. 10, No. 10, 2020, E-ISSN: 2222-6990 @ 2020 HRMARS

brief, the high cost of implementation which includes the cost of changes and cost of compliance will hinder the restaurant industry players to adopt halal certification although they perceive it is meaningful to the business.

\section{Consumer Awareness and Demand}

In Malaysia, only $22.3 \%$ of 600 respondents perceived that the halal logos displayed in the restaurants are trustworthy (Ali et al., 2016). Muslim consumers are looking for price, taste and surrounding instead of halal logo when selecting a food outlet to patronize in Klang Valley area (Ahmad et al., 2013) whereas the top three factors that influence the intention of consumers to purchase a product were promotion, place, attractive and quality yet the halal certification was the fourth factor although $94 \%$ of the participants were Muslims (Nooh, Nawai, Mohd Dali, \& Mohammad, 2007). Added to that, there are still Muslims who dine at the halal claimant restaurants without halal logo or 'pork-free' restaurants with 'pork-free' signage (Ali et al., 2016). There are five factors that influence the patronage of Muslim in halal claimant restaurants, which are trust, cleanliness, food safety, traceability and culture. In terms of culture, majority of the Muslims prefer to ear at 'warung' or road sites without concerning on the existence of the halal logo in which the practice is inherited from generation to generation. In contrast, the Muslim consumers are looking at the halal status when they are selecting restaurants in Seri Iskandar, Perak, Malaysia (Akbar \& Alaudeen, 2012). But, generally the studies showed that there is a lack of awareness towards halal certification and logo among the Muslim consumers despite halal certification should be the prior criteria that they should look for. The reason may be the Muslim consumers have a "take for granted" attitude by assuming all the food products and food outlets are halal-certified (Ahmad et al., 2013); In addition, they have a tolerant attitude to dine at a restaurant that is non-halal certified (Prabowo et al., 2015). Consequently, the lack of awareness among Muslim consumers leads to lack in demand from consumers to the restaurant industry players to adopt halal certification.

\section{The Theory of Planned Behaviour}

The theory of planned behavior (TPB) which was suggested by Ajzen (1991) is generally recognized as a useful model in predicting and understanding the human behaviors. It has been used in studying halal food purchasing behavior in general and in specific group; for example non-Muslims, in Malaysia (Aziz \& Chok, 2013; Shah Alam \& Mohamed Sayuti, 2011), studying the religion factor influence on halal meat consumption decision making (Bonne, Vermeir, \& Verbeke, 2009), and studying the attitude of young consumers towards halal certification (Khalek, 2014). In the model, there are three main components namely attitude, subjective norm and perceived behavioral control (PBC). 
INTERNATIONAL JOURNAL OF ACADEMIC RESEARCH IN BUSINESS AND SOCIAL SCIENCES Vol. 10, No. 10, 2020, E-ISSN: 2222-6990 @ 2020 HRMARS

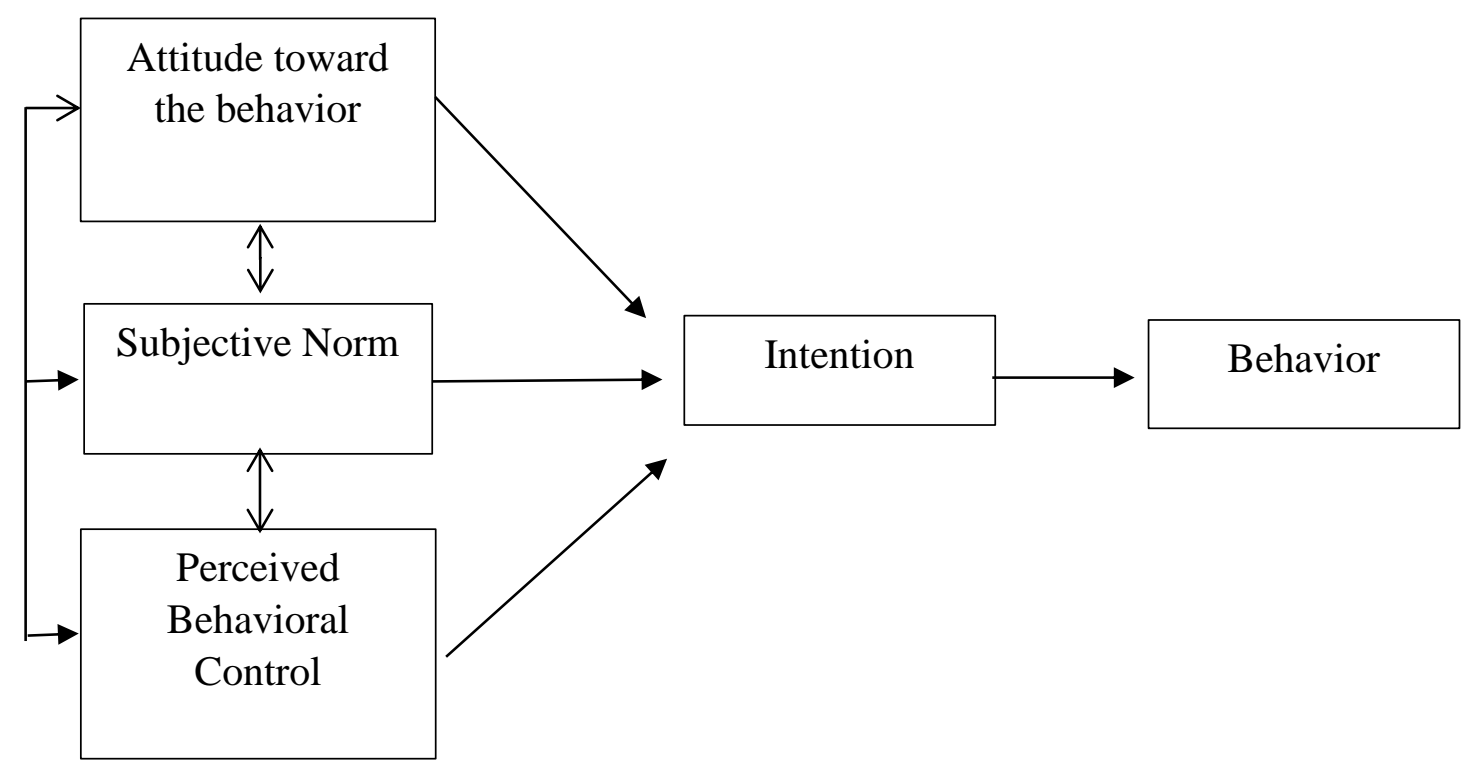

Figure 2: The theoretical framework of theory of planned behaviour. Adapted from "The Theory of Planned Behaviour", by Ajzen, 1991, Organizational Behavior and Human Decision Processes, 50. P. 182.

Attitude towards the behaviour in this context refers to the perception of restaurant managers towards halal certification adoption. The restaurant managers' perception towards adoption of halal certification will be the item in this attitude category. As a general rule, the more important the restaurant managers perceive halal certification, the stronger the intention to adopt the halal certification.

Regarding the subjective norm, religion was suggested by Rahman et al. (2011) since recent studies revealed that religion plays an important role in influencing the consumer's intention and behaviour (Dindyal \& Dindyal, 2004). However, religion is not suited to this research because religion of the restaurant managers does not affect the decision making of adopting the halal certification. Based on the exploratory research of understanding the attitude of restaurant managers towards halal certification (Syed Marzuki et al., 2014), the finding suggested that restaurant managers agreed that halal certification is important regardless of races and religion. The possible item in this context should be the restaurants with 'pork-free' signage which is prevalent nowadays in Malaysia, especially in Kuala Lumpur (Haroun et al., 2014). The prevalence of adopting 'pork-free' signage in restaurant industry as an advertising strategy will influence the perceived importance level of halal certification adoption and also the intention to adopt halal certification.

According to Rahman et al. (2011), seven items were suggested categorized in PBC, in which lack of knowledge, supplier and governance issues were the top three elements that contribute to the behaviour of non-compliance among restaurant operators. In an exploratory study that was carried out in East Kalimantan Indonesia, eleven factors were revealed and categorized into internal and external factors in general (Prabowo et al., 2015). Furthermore, a total of 36 motivation and 37 limitation factors were identified in implementation of halal certification (Ab Talib et al., 2015). By 
comparing and contrasting the factors of studies, knowledge and halal awareness of restaurant industry players, cost of implementation, supplier issue, consumer awareness and demand and certification procedure are the main hindering factors while food safety and quality, market expansion, inter-restaurant competition, demand from consumers and environmental friendly are main motivating factors. Those factors are considered as PBC, and they are expected to have an impact on the attitude since the factors will encourage or discourage the restaurant managers to perceive the significance of adoption of halal certification and also contribute to the intention of adopting halal certification.

\section{Methodology}

In this study, the research approach used is qualitative research. This is because qualitative research allows the researcher to generate greater insights (Low \& Cheng, 2004) or to obtain a rich understanding of a new phenomenon (Tieman, 2011), where the low perceived importance level of adopting halal certification among restaurant operators is one of the new phenomenon that little studies has been done on this phenomenon. Phenomenological design was used for this research since non-adopting halal certification of a pork free restaurant is more prevalent and has become a popular phenomenon. Moreover, some news articles have risen up the issue that there are non-halal certified restaurants display 'pork-free' signage which have caused the people especially Muslim customers' confusion (Balakrishnan, 2016; Divakaran, 2016; Ismail, 2016; Lim, 2016). The informants for this study were restaurant owners and managers from the casual dining restaurants in IOI City Mall, Putrajaya. For the sampling method, this study was used non-probability sampling which is purposive sampling, which means only the restaurant operators who are from non-halal certified restaurants are chosen as informants. Appointment is made with the restaurant operators and the interview sessions were carried out in the dining area. A total of 12 restaurant operators became the informants in this study since the data was saturated at this point.

\section{Results}

\section{Demographic Profiles}

There were a total of twelve informants who had shared their thoughts regarding the halal certification. Among the informants, seven of them were males and five were females. Seven of them were restaurant managers while five of them were the owners of the restaurants. There were four Malays, four Chinese, three Koreans and one Nepalese participated in this research.

In terms of food offering, four restaurants served Korean food, four served Western food and two served Japanese and local food respectively. Twelve restaurants were identified as not having the halal certification or halal logo, but their status were different. There were four restaurants in the process of applying the halal certification whereas seven restaurants were not ready to apply the halal certification. There was only one restaurant had the halal certification, but it was in the process of renewing it.

\section{Attitude of Restaurant Operators}

\section{Ambivalent Attitude towards Halal Certification}

Based on the findings, six of the total informants had ambivalent feeling towards halal certification adoption. They felt that halal certification adoption is important, but they did not intend 
INTERNATIONAL JOURNAL OF ACADEMIC RESEARCH IN BUSINESS AND SOCIAL SCIENCES Vol. 10, No. 10, 2020, E-ISSN: 2222-6990 @ 2020 HRMARS

to apply for it due to the hindering factors. The main reason that they feel halal certification adoption is essential was Muslim customers' demand. Regarding this factor, the explanations were:

'It is important in Malaysia, because Muslims always look for it. But not every restaurant can obtain the halal certification.' (Mr. W, Restaurant M)

'It might be not so important for other countries, but it is important in Malaysia because it is a Muslim country.' (Mr. P, Restaurant Z)

Besides, target market demand was also the reason that informants felt halal certification adoption was important. This finding was consistent with the study carried out on non-halal certified restaurants in Klang Valley where the respondents believed that halal certification is not essential since majority of their patrons were non-Muslims (Rosnan, Osman, Mat Nor, \& Aminuddin, 2015). For instance, $\mathrm{Mr}$. J of restaurant $\mathrm{K}$ felt the halal certification adoption is important, yet he did not intend to apply for it since his target market was Korean tourists.

'I think it is important but we cannot apply that because our restaurant is targeting the Korean tourists.' (Mr. J, Restaurant K)

\section{Advocating of Halal Certification}

Five informants were advocating of halal certification and intended to adopt halal certification in time. The reasons were Muslim customers' demand, market expansion, and food safety. The findings were corresponding with the themes suggested, such as demand of Muslims, religion obligation of Muslims, confidence level of Muslims, safety of food, cleanliness, and marketing purposed by two previous studies (Inam, Janjua, \& Malik, 2016; Syed Marzuki, 2012; Syed Marzuki et al., 2012).

Regarding the Muslim customers' demand, which was the same suggested by the informants with ambivalent feeling, the informants explained that the largest Muslim population had led to huge demand on halal food. Furthermore, halal certification will increase the confidence of Muslim customers since it guarantees the food is halal which can fulfill their demand. This reason was parallel with Islamic attributes, which indicated the increased demand of Muslim customers and halal certification increases their confidence, suggested by the previous study by using factor and cluster analysis (Syed Marzuki et al., 2014). These were their comments on the Muslim customers' demand:

'It is very important because it is related to the religion obligation of Muslims which they really care about the intake of food, whether it is halal or not.' (Mr. M, Restaurant P)

'If a restaurant has a halal certification, they will have more confidence towards the restaurant since some of the Muslims are very fussy. They look for the halal certification in a restaurant because it is very important for them. For Muslims, halal food is what they consume that builds their blood and body.' (Mr. K, Restaurant F)

In addition, two informants mentioned that market expansion as the reason of feeling halal certification adoption is important. By adopting halal certification, both Muslim and non-Muslim customers will patronize the restaurant. This is being proved by a previous study which found that non-Muslim had high confidence level towards halal food products and higher purchase intention (Golnaz, Zainalabidin, Mad Nasir, \& Eddie Chiew, 2010). This finding was consistent with the previous 
INTERNATIONAL JOURNAL OF ACADEMIC RESEARCH IN BUSINESS AND SOCIAL SCIENCES

Vol. 10 , No. 10, 2020, E-ISSN: 2222-6990 @ 2020 HRMARS

studies that have highlighted the marketing benefits brought by halal certification (Syed Marzuki et al., 2012, 2014). Their comments were mentioned as follows:

'From a businessman view, if we apply halal certification, we can bring more and more customers. They will come in to the restaurant automatically if they see halal certification.' (Mr. K, Restaurant K)

'Besides, having a halal certification also can attract more Muslim customers to dine in. Conversely, we will have certain customers only if we do not have a halal certification.' (Mr. $M$, Restaurant $P$ )

Last but not least, one informant had mentioned food safety was the reason to adopt halal certification. This is because halal-certified ingredients will be safe to consume and clean. This finding was in line with previous study that suggested restaurant managers had considered food quality as one of the halal certification's attributes (Syed Marzuki, 2012). Also, this factor was compatible with 'market signal', where it indicated halal certification attributes such as food quality, safety and hygiene, suggested by another study (Syed Marzuki et al., 2014). She pointed out that:

'It is important. This is for food safety. The ingredients must not contain pork or indirectly contact with pork and also dog. Besides, it is important for cleanliness. For example, we cannot accept the eggs which are not being washed properly. The eggs should be washed according to halal standard.' (Ms. N, Restaurant P)

\section{Opposing Attitude towards Halal Certification}

Lastly, one informant had opposing feeling towards halal certification adoption. Halal certification was not significant due to the Muslim customers' high acceptance from her point of view. This was an exceptional finding which contradicts to the previous study that suggested restaurant operators were generally aware the importance of halal certification, including Muslim and non-Muslim (Syed Marzuki et al., 2012). She shared that:

'It is not really important for me because nowadays people are more open-minded and they don't really look for a halal certification.' (Ms. G, Restaurant T)

In conclusion, the informants in this research can be classified into three groups based on their attitudes, which are advocate, ambivalent and opposing attitude towards adoption of halal certification.

\section{Hindering Factors}

\section{Presence of Non-Halal Ingredients}

Six informants had mentioned presence of non-halal ingredients like alcohol and imported goods had hindered them from adopting halal certification. One informant from Korean-themed and one informant from Japanese-themed restaurant shared the same thought that serving alcoholic beverages was the original culture from Korea and Japan. Two informants' explanations were: 
INTERNATIONAL JOURNAL OF ACADEMIC RESEARCH IN BUSINESS AND SOCIAL SCIENCES Vol. 10, No. 10, 2020, E-ISSN: 2222-6990 @ 2020 HRMARS

'Actually our restaurant is not $100 \%$ halal. This is just pork-free restaurant. We never ever talk to customers that this is halal restaurant, we don't serve pork, but we have some alcohol for the tourist customers from Korea.' (Mr. J, Restaurant K)

'The Singaporeans do not intent to follow the Malaysian culture because they follow the Japanese culture, in which we have to have Sakae, alcohol or beer with sushi. This is because Japanese always eat sushi with beer, or they have to have the Sakae.' (Ms. C, Restaurant S)

Besides, imported goods from foreign country like Japan, Korea and Taiwan which were nonhalal certified were used in the preparation of food. One of the informants' justifications was as follows:

'90\% of the food is halal only. Another $10 \%$ are imported from Korea which is not halalcertified.' (Mrs. J, Restaurant S)

The presence of non-halal ingredients in the restaurant had disqualified the restaurant from obtaining a halal certification because the requirements of getting halal certification includes prohibited usage of non-halal food and beverages in the premise and liquor or liquor-based materials in the kitchen (Jabatan Kemajuan Islam Malaysia, 2015). This finding was consistent with the previous study that had found serving alcoholic beverages or serving pork free dishes with non-halal certified ingredients are one of the major reasons of not adopting halal certification (Rosnan, Osman, Mat Nor, \& Aminuddin, 2015).

\section{Application of Halal Certification}

The second factor is application of halal certification. The bureaucracy, application cost and stringent criteria of applying halal certification had driven away the informants. Firstly, two informants felt that applying for halal certification was time consuming which was in line with previous studies (Ab Talib et al., 2015; Noordin et al., 2009; Noordin, Noor, \& Samicho, 2014; Prabowo et al., 2015). Likewise, a newspaper article had disclosed the thought of Malaysian eateries towards halal certification and majority has voted bureaucracy and time consuming as the reasons for foregoing the application of halal certification (Azlee, 2016). One of the informants explained that he did not know when the procedure will be completed and when can he got the halal certification.

'We are applying but we don't know when we will get the halal certification. The procedure is a long process and we have to wait...It is already one-year applying...I think they are checking the materials, but I am not really sure what JAKIM request.' (Mr. K, Restaurant F)

For the stringent criteria of applying halal certification, Muslim staff requirement was highlighted by one informant. The requirement of hiring at least two Muslim workers at production area was difficult to be fulfilled because the present workers were mostly foreign workers. This finding was again matched with the previous study that had raised up the same issue that restaurant operators preferred to hire foreign workers rather than Muslim workers because Muslim workers were intolerance to the less ideal working condition and had high expectation of salary (Najiha, Abdul, Othman, Fatimah, \& Zainal, 2017; Rosnan et al., 2015). The informant comment was as follows: 
INTERNATIONAL JOURNAL OF ACADEMIC RESEARCH IN BUSINESS AND SOCIAL SCIENCES Vol. 10, No. 10, 2020, E-ISSN: 2222-6990 @ 2020 HRMARS

'As far as I know, every shift must have minimum two Muslims workers. But most of the workers of our restaurant are foreigners and non-Muslims. This request is difficult for us to fulfill.' (Mr. K, Restaurant F)

Lastly, one informant claimed that application cost for halal certification was very expensive since he had consulted from his acquaintances. This finding was consistent with a newspaper article which found that a restaurant owner also reflected that the huge consultancy fees and bureaucracy procedure made him to forego the plan of applying halal certification (Azlee, 2016). The comment of the informant was:

'Before this, I had asked about how to apply the certification but it is too expensive for me... I am not sure about the exact amount that has to pay. I just heard that it is expensive because I have a friend who knows someone who works in the JAKIM.' (Mr. W, Restaurant M)

\section{Consumer-Employee Interaction}

Last but not least, low consumer-employee interaction was supported by most of the informants, which means not every customer will concern about the halal status of the restaurant and ask the employee about it. This can be proved by the comment:

'Not many will ask about that, it can be said that there are only one out of hundred.' (Mr. $P$ of Restaurant Z)

In addition, the informants claimed that normally the Muslim customers will patronize the restaurant after the informants had explained and shown them the halal certification of supplier. This finding was parallel to study of Rosnan et al. (2015) where they found that the customers concerned more on the halal status of the food that the restaurant offer rather than the halal status of the restaurant itself. The reason might be the trust of customers towards the restaurant operators rather than trust the display of halal logo at the restaurant (Ali et al., 2016; Rosnan et al., 2015). The comment of one informant was:

'Yes, some of the customers will ask whether we have halal certification or not. Some of the customers will choose not to come in after explaining. However, we will always explain our food is halal although we don't have the halal certification whenever the customers are asking. Around $70 \%$ of the customers will come in.' (Mr. K, Restaurant F)

All in all, the three factors were partly consistent with the similar study at East Kalimantan Indonesia where financial constraint, certification procedure and low of consumer awareness and demand are identified (Prabowo et al., 2015). Meanwhile, this finding was not consistent with a previous study that had found lack of knowledge, supplier and governance issue were the main factors contributed to the non-compliance behavior (Nur et al., 2011). A critical question raised up: since Muslims are willing to patronize a restaurant without a halal certification, then why would they apply for it? 
INTERNATIONAL JOURNAL OF ACADEMIC RESEARCH IN BUSINESS AND SOCIAL SCIENCES Vol. 10, No. 10, 2020, E-ISSN: 2222-6990 @ 2020 HRMARS

\section{'Pork-Free' Signage}

In general, majority of the informants understood what 'pork-free' signage is. 'Pork-free' signage means free from pork ingredients, in which the restaurant is not serving any dishes that containing pork or pork-related ingredients. However, the restaurant might serve alcoholic beverages which were supported by two informants' comments and this was parallel with two newspaper articles (Balakrishnan, 2016; Lim, 2016).

'For me, pork-free doesn't mean that it is halal, but it is just telling the people that the restaurant is not serving pork. Sometimes, the restaurants still serve the alcohol.' (Mr. M, Restaurant $P$ )

'It means the restaurant does not serve anything that has pork. This is because the restaurant may serve alcohol. It means the food is okay to eat, but they cannot get the halal certification due to the drinks.' (Mr. K, Restaurant F)

\section{'Pork-Free' Effect on Attracting Muslim Customers}

Based on the findings, majority of the informants claimed that the 'pork-free' signage cannot attract Muslim customers due to customer faith and customer choice. Two informants shared that Muslim customers will still have doubt towards the halal status of the restaurant and the food offered which can be shown below:

'No, it can only attract non-Muslim customers. Not 100\% Muslims will dine in the pork-free restaurant...sometimes the restaurant still serve the alcohol' (Mr. $M$, Restaurant $P$ )

'It is hard because they still have doubt even though the restaurant says it is pork-free. They don't know why they put the signage.' (Mr. K, Restaurant F)

Conversely, 'pork-free' signage did not influence Muslim customers' choice to patronize the restaurant according to one informant. They might ask the staff or look at the menu before entering the restaurant. Hence, the signage is not displayed for attracting Muslim customers. The signage might be displayed for other religions' devotees who do not consume pork, but not for Muslim customers (Kaur, 2016; "Ministry to explain definition of ' pork-free ' signage," 2016). As commented by the informants:

'Some yes, some no. We cannot say for certain because it depends on the individual's mind. This is because some thinks that no pork but it still have alcohol.' (Ms. C, Restaurant S)

Based on the observation, three out of twelve restaurants displayed 'no pork' signage. The purpose of displaying the signage was to target Muslim customers which were agreed by two informants. Another informant claimed that it was a communication tool to inform customers that the restaurant did not serve pork dishes. This perception was supported by newspapers articles that found displaying 'pork-free' signage was to inform the public about the food served by the restaurant is free from pork (Kaur, 2016; "'No pork' restaurants can be penalised for trying to confuse Muslims, says ministry officer," 2016). The comments were as follows: 
INTERNATIONAL JOURNAL OF ACADEMIC RESEARCH IN BUSINESS AND SOCIAL SCIENCES Vol. 10, No. 10, 2020, E-ISSN: 2222-6990 @ 2020 HRMARS

'The tag is just to inform but not attract them. It depends on them whether they want to come inside or not. They can look at the menu at the entrance to decide they want to dine in or not.' (Ms. G, Restaurant T)

'Of course, not only our restaurant, there are many Korean restaurants also have the tag, they are also selling the sojiu, but the most of the customers are Muslims.' (Mr. J, Restaurant K)

'This is because majority of the population in Putrajaya is Muslims... For your information, it is harder if we target Chinese customers only because their spending power is not as strong as Muslim customers.' (Mr. W, Restaurant M)

In a nutshell, the two purpose of displaying 'pork-free' signage are to inform the public about the restaurant offers dishes that free from pork ingredients; to the contrarily, to target Muslim customers. Also, generally the informants think that 'pork-free' signage has less effect on attracting Muslim customers due to customer faith and choice.

\section{Discussion}

Based on the findings, attitude of restaurant operators (perceived importance level towards halal certification adoption), subjective norm ('pork-free' restaurants) and perceived behavioral control (hindering factors) did influence the intention of adopting halal certification. Specifically, the PBC and attitude of restaurant operators have negative relationship with intention of adopting halal certification. At the same time, subjective norm has the lowest influence on shaping the behavior.

Negative relationship between PBC and intention of halal certification adoption is the most significant in this research context. As a general rule in TPB, the greater the perceived level of difficulty of performing the behavior, the lower the intention of performing the behavior (Ajzen, 1991). Likewise, the stronger the hindering factors of adopting halal certification, the lower the intention of halal certification adoption. In PBC, the control beliefs have shaped the perception of behavioral control by believing in the past experience and the experiences of acquaintances and friends. For instance, one informant in this research has perceived that the halal certification application cost is expensive according to his acquaintance; hence, he refuses to apply because the perceived difficulty level is high. In short, the relationship between PBC and intention of halal certification adoption is negative and significant.

In terms of attitude of restaurant operators, it is corresponding to the intention of halal certification adoption. In other words, favorable attitude of restaurant operators towards halal certification provide a basis for greater intention of adopting halal certification. However, the majority of informants who advocate of halal certification adoption have behavior that is not parallel by showing less intention of adopting the halal certification. This is because a significant relationship is identified between attitude of restaurant operators and PBC whereby the attitude of restaurant operators is influenced by PBC. This relationship is confirmed because the restaurant operators refuse to apply for halal certification due to hindering factors. Although the attitude of restaurant operators shows great intention of adopting halal certification, it is influenced by PBC and thus the relationship between attitude of restaurant operators and intention become negative. Therefore, 
INTERNATIONAL JOURNAL OF ACADEMIC RESEARCH IN BUSINESS AND SOCIAL SCIENCES Vol. 10, No. 10, 2020, E-ISSN: 2222-6990 @ 2020 HRMARS

PBC not only has direct influence on the intention of adopting halal certification, but it also has influence on attitude of restaurant operators and then on the intention of adopting halal certification.

Meanwhile, the subjective norm, which refers to the pork free restaurant, shows a little influence towards intention of restaurant operators to adopt halal certification. It is consistent with the result that religion as the subjective norm shows an insignificant relationship with behaviour of non-compliance of the halal standards among restaurant operators (Nur et al., 2011). Since the informants show their preference on halal certification rather than 'pork-free' signage, it suggests that the existence of 'pork-free' signage does not affect the intention of adopting halal certification.

In conclusion, attitude of restaurant operators and PBC have negative relationship with the intention to adopt halal certification, whereas the subjective norm has lowest influence towards the intention of halal certification adoption.

\section{Conclusion}

This research finding not only reviews the general perception of the restaurant operators of non-halal certified restaurants towards halal certification, but also reviews the 'pork-free' signage in restaurant industry. Restaurant operators, especially the owners must plan in advance whether they want to adopt halal certification or not so that they can have a direction on what kind of menu provide to customers, target market and staffing. The scenario of not using $100 \%$ halal ingredients but target Muslim customers' can be avoided provided that strategic planning has been done before.

Besides, this research also reflects the ineffective searching of information about halal certification. The non-certified halal restaurant operators do not have a clear idea on the exact application fees and all the criteria for applying halal certification. Restaurant operators should search for the information actively, from website, authority, consultants and also from friends, at the same time, double confirm the information obtained. After gaining a clear picture of what should be done for applying halal certification, the time taken for completing the application procedure can be shorten.

On the other hand, Muslim consumers should increase their awareness towards the halal status of the restaurants when dining out. The restaurants without halal certification and 'pork-free' signage should be keep an eye too because the 'unknown' status will create doubt. In this research, surprisingly a restaurant with 'unknown' status claim that certain of their menu items actually contain alcohol, but it should be fine for Muslims to consume because the alcohol will be evaporated when cooking. This thinking reflects the restaurant operators did not have a good understanding towards the halal concept hence they tried to 'persuade' Muslims consumers to dine at their restaurant. All in all, Muslim consumers should be more alert to these type of restaurants to avoid unforeseen circumstance from occur and stay in a good faith.

\section{Corresponding Author}

Associate Prof. Dr. Hazrina Ghazali

Department of Food Service Management

Faculty of Food Science and Technology 
INTERNATIONAL JOURNAL OF ACADEMIC RESEARCH IN BUSINESS AND SOCIAL SCIENCES

Vol. 10, No. 10, 2020, E-ISSN: 2222-6990 @ 2020 HRMARS

Universiti Putra Malaysia

43400 UPM Serdang, Selangor.

Email: hazrina@upm.edu.my

\section{References}

Ab Talib, M. S., Abdul Hamid, A. B., \& Ai Chin, T. (2015). Motivations and limitations in implementing Halal food certification: a Pareto analysis. British Food Journal, 117(11), 26642705. https://doi.org/10.1108/BFJ-02-2015-0055

Ab Talib, M. S., Ai Chin, T., \& Fischer, J. (2017). Linking Halal food certification and business performance. British Food Journal, 119(7), 1606-1618. https://doi.org/10.1108/BFJ-01-20170019

Abdul Manaf, B., Cheng, W. H., \& Nurwahida, F. (2013). The competitiveness of halal food industry in Malaysia : A SWOT - ICT analysis. Journal of Society and Space, 1(1), 1-9.

Ahmad, N. A., Abaidah, T. N. T., \& Yahya, M. H. A. (2013). a Study on Halal Food Awareness Among Muslim Customers in Klang. 4Th International Conference on Business and Economic Research Proceeding, (March), 1073-1087.

Ajzen, I. (1991). The Theory of Planned Behavior. Organizational Behaviour and Human Decision Processes, 179-211. https://doi.org/10.1016/0749-5978(91)90020-T

Akbar, Y., \& Alaudeen, M. (2012). Determinant of factors that influence consumer in choosing normal full-service restaurant: case in Seri Iskandar, Perak. South East Asian Journal of Contemparary Business Economics and Law, 1(2012), 137-145.

Ali, R., Marzuki, S. Z. S., Kader, M. A. R. A., \& Mat Yunus, N. K. (2016). Factors Affecting Patronizing Halal Claimant Restaurant Among Muslims Customers Muslims Customers, (May). https://doi.org/10.13140/RG.2.1.1956.6965

Awan, H. M., Siddiquei, A. N., \& Haider, Z. (2015). Factors affecting Halal purchase intention evidence from Pakistan's Halal food sector. Management Research Review, 38(6), 640-660. https://doi.org/10.1108/MRR-01-2014-0022

Aziz, Y. A., \& Chok, N. V. (2013). The Role of Halal Awareness, Halal Certification, and Marketing Components in Determining Halal Purchase Intention Among Non-Muslims in Malaysia: A Structural Equation Modeling Approach. Journal of International Food and Agribusiness Marketing, 25(1), 1-23. https://doi.org/10.1080/08974438.2013.723997

Azlee, A. (2016). Halal certification : What Malaysian eateries really think. Malay Mail Online, pp. 17. Retrieved from http://www.themalaymailonline.com/malaysia/article/halal-certificationwhat-malaysian-eateries-really-think\#BjiP7zjrlETSjR8V.97

Balakrishnan, N. (2016). “Know The Difference between 'Pork-Free' And Halal," Says Deputy Minister From PM's Office. Says. Retrieved from http://says.com/my/news/pork-free-label-inrestaurants-are-misleading-to-muslim-customers

Bonne, K., Vermeir, I., \& Verbeke, W. (2009). Impact of religion on halal meat consumption decision making in Belgium. Journal of International Food and Agribusiness Marketing, 21(1), 5-26. https://doi.org/10.1080/08974430802480628

Dindyal, S., \& Dindyal, S. (2004). How Personal Factors, Including Culture And Ethnicity, Affect The Choices And Selection Of Food We Make. The Internet Journal of Third World Medicine, 1(2), 2-5. https://doi.org/10.5580/2231

Divakaran, P. (2016). Jakim : ' Pork Free', ' No Pork' signs at restaurants can confuse Muslims. The 
INTERNATIONAL JOURNAL OF ACADEMIC RESEARCH IN BUSINESS AND SOCIAL SCIENCES Vol. 10, No. 10, 2020, E-ISSN: 2222-6990 @ 2020 HRMARS

Star Online. Retrieved from https://www.thestar.com.my/news/nation/2016/02/16/jakimpork-free-no-pork-do-not-mean-food-is-halal/

Golnaz, R., Zainalabidin, M., Nasir, M. S., \& Eddie Chiew, F. C. (2010). Non-muslims' awareness of Halal principles and related food products in Malaysia. International Food Research Journal, 17(3), 667-674. https://doi.org/10.1108/JIMA-04-2014-0033

Halal Tourism Explained. (2014). The Star Online. Retrieved from https://www.thestar.com.my/travel/malaysia/2014/10/13/halal-tourism-explained/

Haroun, M., Zahri, M., Hemdi, M., \& Zulkifly, M. (2014). Pork free restaurants in Malaysia: Issue of halal and Muslim customer patronization. Hospitality and Tourism, (November 2015).

Inam, S., Janjua, S. Y., \& Malik, S. A. (2016). Managerial Perception Toward Halal Certification : Study of International Food Chains in. Pakistan Business Review, (April 2016), 179-195.

Ismail, F. (2016). Halal, pork-free and we, the consumers. New Straits Times; Kuala Lumpur. Retrieved from https://www.nst.com.my/news/2016/02/129457/halal-pork-free-and-weconsumers

Jabatan Kemajuan Islam Malaysia. (2015). Manual Procedure for Malaysia Halal Certification (Third Revision) 2014. Manual Procedure for Malaysia Halal Certification (Third Revision) 2014, 67. https://doi.org/10.1017/CBO9781107415324.004

Kaur, M. (2016). Jakim has no power to take action over ' Pork Free', ' No Pork' signs. The Star Online, p. 10894. Retrieved from https://www.thestar.com.my/news/nation/2016/02/18/jakim-no-action-pork-free-free-pork/

Khalek, A. A. (2014). Young Consumers' Attitude towards Halal Food Outlets and JAKIM's Halal Certification in Malaysia. Procedia - Social and Behavioral Sciences, 121(September 2012), 2634. https://doi.org/10.1016/j.sbspro.2014.01.1105

Lim, I. (2016). Jakim: No official complaints on "pork-free" signs. Malay Mail Online. Retrieved from http://www.themalaymailonline.com/print/malaysia/jakim-no-official-complaints-on-porkfree-signs

Low, P., \& Cheng, K. (2004). The Brand Marketing of Halal Products: The Way Forward. Journal of Brand Management, 5(4), 38-50.

Malaysia External Trade Development Corporation. (2017). 14th Malaysia International Halal Showcase Post Show Report. Kuala Lumpur. Retrieved from http://mihas.com.my/downloads/MIHAS2017_postshowreport_lowres.pdf

Message, C., Self-, F., State, F. S., Under, N., Joining, D., Negara, I., ... Govt, S. (2018). No Halal Certificate But Still ' Halal ', 1-2.

Ministry to explain definition of 'pork-free' signage. (2016, February 15). Malay Mail Online, pp. 16. Retrieved from http://www.themalaymailonline.com/malaysia/article/ministry-to-explaindefinition-of-pork-free-signage\#emA8u30FrXfIECRt.97

Najiha, A., Abdul, R., Othman, M., Fatimah, U., \& Zainal, U. (2017). Critical success factors affecting the implementation of halal food management systems : Perspective of halal executives, consultants and auditors. Food Control, 74, 70-78. https://doi.org/10.1016/j.foodcont.2016.11.031

'No pork' restaurants can be penalised for trying to confuse Muslims, says ministry officer. (2016). Malay Mail Online, pp. 1-10. Retrieved from http://www.themalaymailonline.com/malaysia/article/no-pork-restaurants-can-be-penalisedfor-trying-to-confuse-muslims-says-min\#X2IB2hQWEezVFsre.97 
INTERNATIONAL JOURNAL OF ACADEMIC RESEARCH IN BUSINESS AND SOCIAL SCIENCES Vol. 10, No. 10, 2020, E-ISSN: 2222-6990 @ 2020 HRMARS

Nooh, M. N. M., Nawai, N., Dali, M. N. R. S., \& Mohammad, H. (2007). Halal branding: An exploratory research among consumers in Malaysia. Proceedings of 3rd ..., 16-18.

Noordin, N., Hashim, M., \& Samicho, Z. (2009). VALUE CHAIN OF HALAL CERTIFICATION SYSTEM : A CASE OF THE MALAYSIA HALAL INDUSTRY Nurulhuda Noordin ,. European and Mediterranean Conference on Information Systems 2009 (EMCIS2009), 2009(2008), 1-14. https://doi.org/10.1108/JIMA-03-2014-0027

Noordin, N., Noor, N. L. M., \& Samicho, Z. (2014). Strategic Approach to Halal Certification System: An Ecosystem Perspective. Procedia - Social and Behavioral Sciences, 121(September 2012), 79-95. https://doi.org/10.1016/j.sbspro.2014.01.1110

Nordin, N. (2009). Greater awareness, more options boost halal market. New Straits Times; Kuala Lumpur, pp. 8-11. Retrieved from https://search.proquest.com/docview/272223988?accountid=27932

Nur, I., Rahman, A., Saleh, R., Rahman, S. A., \& Hashim, D. M. (2011). Factors Contributing to NonCompliance of the Halal Standard among Restaurant Operators in Malaysia. 2nd International Conference on Business, Economic and Tourism Management, 24, 88-92.

Prabowo, S., Abd Rahman, A., Ab Rahman, S., \& Samah, A. A. (2015). Revealing factors hindering halal certification in East Kalimantan Indonesia. Journal of Islamic Marketing, 6(2), 268-291. https://doi.org/10.1108/JIMA-05-2014-0040

Qu, S. Q., \& Dumay, J. (2011). The qualitative research interview. Qualitative Research in Accounting \& Management (Vol. 8). https://doi.org/10.1108/11766091111162070

Rezai, G., Mohamed, Z., \& Shamsudin, N. M. (2012). Non-Muslim consumers' understanding of Halal principles in Malaysia. Journal of Islamic Marketing, 3(1), 35-46. https://doi.org/10.1108/17590831211206572

Rosnan, H., Osman, I., Nor, M. N., \& Aminuddin, A. (2015). Halal certification: An exploratory study on non-certified restaurants. Advanced Science Letters, 21(6), 1854-1857. https://doi.org/10.1166/asl.2015.6136

Shafie, S., \& Othman, M. N. (2006). Halal Certification : an international marketing issues and challenges. Proceeding at the International IFSAM VIIIth World Congress, 1-11.

Shafiq, A., Haque, A. K. M., \& Omar, A. (2015). Multiple halal logos and Malays' beliefs: A case of mixed signals. International Food Research Journal, 22(4), 1727-1735.

S Alam, S., \& Sayuti, M. N. (2011). Applying the Theory of Planned Behavior (TPB) in halal food purchasing. International Journal of Commerce and Management, 21(1), 8-20. https://doi.org/10.1108/10569211111111676

Marzuki, S. Z. (2012). Understanding Restaurant Managers' Expectations of Halal Certification. University of Canterbury.

Marzuki, S. Z., Hall, C. M., \& Ballantine, P. W. (2012). Restaurant managers' perspectives on halal certification. Journal of Islamic Marketing, 3(1), 47-58. https://doi.org/10.1108/17590831211206581

Marzuki, S. Z., Hall, C. M., \& Ballantine, P. W. (2014). Measurement of Restaurant Manager Expectations toward Halal Certification Using Factor and Cluster Analysis. Procedia-Social and Behavioral Sciences, 5(4), 291-303. https://doi.org/10.1016/j.sbspro.2014.01.1130

Talib, Z., Zailani, S., \& Zainuddin, Y. (2010). Conceptualizations on the Dimensions for Halal Orientation for Food Manufacturers: A Study in the Context of Malaysia. Pakistan Journal of Social Sciences. https://doi.org/10.3923/pjssci.2010.56.61 
INTERNATIONAL JOURNAL OF ACADEMIC RESEARCH IN BUSINESS AND SOCIAL SCIENCES

Vol. 10, No. 10, 2020, E-ISSN: 2222-6990 @ 2020 HRMARS

The Guardian. (2017). Halal tourism: Kuala Lumpur welcomes the Muslim travellers others didn't want. The Guardian. Retrieved from https://www.theguardian.com/cities/2017/jun/06/halaltourism-kuala-lumpur-muslim-travellers-malaysia

Tieman, M. (2011). The application of Halal in supply chain management: in-depth interviews. Journal of Islamic Marketing, 2(2), 186-195. https://doi.org/10.1108/17590831111139893

Yunos, R. M., Mahmood, C. F. C., \& Mansor, N. H. A. (2014). Understanding Mechanisms to Promote Halal Industry-The Stakeholders' Views. Procedia - Social and Behavioral Sciences, 130, 160166. https://doi.org/10.1016/j.sbspro.2014.04.020

Yusuf, A. H., Shukor, S. A., Salwa, U., \& Bustamam, A. (2015). Issues and Challenges of Halal Implementation in Food Industry in Malaysia, 2(2), 173-177.

Zailani, S., Omar, A., \& Kopong, S. (2011). An Exploratory Study on the Factors Influencing the NonCompliance to Halal among Hoteliers in Malaysia. International Business Management.

https://doi.org/10.3923/ibm.2011.1.12 